\title{
The Future Francis Beaumont
}

\begin{abstract}
This essay attends to Beaumont's recent performance and reception history, documenting a range of academic and popular responses to demonstrate the challenges and affordances of engaging with Beaumont's plays. The first section examines several twenty-first century performances of Beaumont plays, focusing especially on the Globe's stimulating production of The Knight of the Burning Pestle. The second section considers how Beaumont was both acknowledged and ignored in 2016, the year of his $400^{\text {th }}$ anniversary. The final section suggests some avenues for further research into the performance of Beaumont's plays.
\end{abstract}

In 1613, illness caused one of the greatest writers of the age to retire from playwrighting, paving the way for his principal collaborator, John Fletcher, to become the main dramatist for the King's Men, the company for whom he had written some of his most popular plays. Three years later, the London literary scene mourned his death. Tributes continued for decades and he was ultimately honoured with the posthumous publication of a handsome folio of his works. This is the familiar story of William Shakespeare. It is also the unfamiliar story of Francis Beaumont.

The comparison of the two authors' deaths I have just offered entails a degree of contrivance. Beaumont seemingly retired because he was incapacitated by a stroke, but Shakespeare's reasons for retiring, and indeed, the nature of his retirement, are much less clear. Beaumont was the subject of a folio collection, but it took decades, rather than years, before the edition was published and, unlike the First Folio edition of Shakespeare's works, it was explicitly advertised as a collaboration, rather than the work of a single author. It did not even contain very many of his plays. These contrivances ostensibly work to Beaumont's advantage by making him appear more like Shakespeare. But the comparison flatters Shakespeare in other respects. For example, we have little evidence that the London literary

Eoin Price (eoin.price@swansea.ac.uk) is lecturer in English Literature at Swansea University. 
scene mourned Shakespeare. Ian Donaldson observes that, unlike the deaths of Sir Philip Sidney, Edmund Spenser, or Ben Jonson, Shakespeare's death was not a public event. ${ }^{1}$ Shakespeare was buried in his hometown, but there is no evidence that anyone in London did anything out of the ordinary to commemorate him. Beaumont, however, was buried at Westminster Abbey, near Spenser and Geoffrey Chaucer. He was the first playwright to be accorded this honour.

Even so, while Shakespeare's story is continually rehearsed, Beaumont's is rarely told. As Peter Holland notes, 'we cannot ... stop ourselves writing and rewriting some version of the Shakespeare biography, addressing the impossible, enjoying the desire, never despairing, always hoping. ${ }^{2}$ Even where detail is sparse, biographers have found ways to tell stories about Shakespeare. By contrast, Philip Finkelpearl's Oxford Dictionary of National Biography entry on Beaumont states, 'it is puzzling that very little is known aside from his publications about the life of someone as important socially and artistically as Beaumont. ${ }^{3}$ David Bevington provides one explanation for the different levels of detail: we 'know more about Shakespeare than any of his contemporaries in the early modern theatre' precisely because 'researchers have been indefatigable in tracking down as much information as possible about England's most famous writer. ${ }^{4}$ Gary Taylor and Terri Bourus argue that Shakespeare's cultural centrality justifies (even necessitates) the perpetual study of his life and works:

if you are at all curious about other people's pleasures, or if you value our civilization, or if you want to persuade others to join your party of No, you must, at least, comprehend why the party of Yes has so successfully institutionalized Shakespeare as our best, most rewarding read, and our most loved writer. ${ }^{5}$

No comparable impulse to read, study, or perform Beaumont exists. No one would argue that Beaumont has been as important to world literature as Shakespeare. But the balance is surely askew. Although Shakespeare and Beaumont shared a quatercentenary year in 2016, Shakespeare received a disproportionate level of attention while Beaumont barely received any coverage at all.

This essay asks two questions. First: how was Beaumont commemorated in 2016? Second: what can be done to give Beaumont the attention he deserves? The essay is split into three sections. The first surveys performances of Beaumont plays in the years building up to 2016. It examines performance reviews and audience responses to assess academic and non-academic attitudes to Beaumont's plays. The second section focuses on the commemoration of Beaumont in 2016. It examines responses to productions of The Woman Hater in the UK and The Maid's Tragedy 
in the USA but it also reflects on the way the Globe and the RSC - the two highest-profile producers of not-Shakespearean drama in the UK - commemorated (or neglected to commemorate) Beaumont in his anniversary year. The final section offers some suggestions for future approaches to Beaumont, considering what performance studies might do raise the profile of Beaumont in the years to come. Paying attention to Beaumont's often-elided performance and reception history, the essay explores the challenges and the affordances of performing Beaumont plays.

\section{Twenty-first Century Beaumont}

According to Karin Brown's database of productions of early modern drama in the UK and the USA, three Beaumont plays received full professional productions between 1960 and 2010: The Knight of the Burning Pestle (six times), The Maid's Tragedy (three times), and A King and No King (once). ${ }^{6}$ Jeremy Lopez provides evidence of further non-professional productions of these plays, as well as productions of Philaster (twice), The Woman Hater (twice), and The Coxcomb (once). ${ }^{7}$ The number of productions of Pestle is sufficient for Lopez to observe that the play is 'easily among the top ten most frequently performed works of Shakespeare's contemporaries on the modern stage'. ${ }^{8}$ This performance tradition might serve as a testimony of the play's theatrical viability but, as Lopez also notes, productions of Pestle often seem compelled to justify the play's relevance and appeal. To a certain extent this is to be expected: the relevance of centuries-old plays need not be automatically assumed; producers of early modern plays should be prepared to think hard about the ways in which their production will connect with new audiences. But these justifications also attest to an anxiety about the reception of not-Shakespearean drama. This anxiety is understandable because some theatre critics are prone to hasty condemnations of early modern plays. These condemnations can stick, especially when issued by influential figures. Pestle is a frequently anthologized play with a comparatively impressive recent stage history but it too has been subject to severe criticism.

In 2005, for example, Anna Mackmin's production of Pestle received a slew of scathing reviews from the mainstream press. Lyn Gardner lay the blame at the door of the production, rather than the play, which she acknowledged is 'astonishing in the radicalism of its conception and construction.' ${ }^{9}$ But other reviewers questioned the quality of Beaumont's writing. Charles Spencer thought that 'Beaumont's satire on the contrasting theatrical styles of smart city comedy and literary romance is hardly going to cut it with a modern audience' and he criticized 
the play's 'insipid' language'. ${ }^{10}$ Fiona Mountford was harsher still, mocking the play's inclusion in the Barbican's Young Genius season, criticizing its metatheatrical devices as cumbersome, and ending with a curt dismissal of the play which serves as a warning to future producers: 'The audience who so disliked this piece when it was first performed have had their judgment soundly vindicated'. ${ }^{11}$ Sarah Hemming's review was kinder, but still sceptical of the play's ability to amuse: 'We can admire it, but because the targets of its satire are of the time, the satire doesn't really bite.' ${ }^{12}$ If a comparatively canonical play like Pestle receives this kind of feedback, what hope for a less canonical one? What hope for the rest of the Beaumont canon? A bad production of A Midsummer Night's Dream (surely there have been many) would not lead to widespread condemnation of Shakespeare, but Beaumont and his contemporaries must play by different rules. Lucy Munro rightfully notes that 'it would take a courageous producer to mount a professional production' of Pestle in the UK, given the excoriation Mackmin's show received. ${ }^{13}$

Thankfully, a courageous producer did emerge in the shape of Shakespeare's Globe. In 2014, Adele Thomas directed Pestle at the Globe's indoor Sam Wanamaker Playhouse (hereafter SWP). Unlike the Mackmin production, Thomas's Pestle received strong reviews from commercial and academic critics. Crucially, these reviews testified to the quality of the play, as well as the production. Citing Dominic Dromgoole (at the time the artistic director of the Globe), Dominic Cavendish praised the play's 'subversive playfulness with theatrical conventions', while Michael Billington suggested that the play went further than Shakespeare in its formal daring. ${ }^{14}$ The production apparently even caused Mountford to rethink her attitude to the play; she wrote: 'Never judge a play by its adjectives, though, for this 1607 satire by Francis Beaumont turns out to be a delight in a vibrant production.' ${ }^{15}$ Some critics were more ambivalent than others - for example, Paul Taylor suggested that the play was 'funnier in theory than in practice' — but Pestle escaped the rough critical treatment it had received from commercial critics nine years earlier. ${ }^{16}$

Social media and blogs provide further evidence of audience attitudes. The responses recorded on social media are useful because they offer a different perspective to commercial or academic reviewing. Blogs and tweets tend to be pithier and earthier than the forms of writing usually served up as evidence of performance criticism. Tweets archived through the production's official hashtag \#SWPBurningPestle attest to the power of the production in appropriately creative, idiomatic language. The Twitter account of the Reading School English Department described the production as a 'metatheatrical mind melt' (@RSEnglishDept; 22 Feb 2014); Chris Martin (@chrismartin1000; 27 Feb 2014) dubbed 
it an 'electric hilarious meta-anarchy', while Kirsty (@cursed_tea; 19 March 2014) praised its 'absolutely batshit meta tomfoolery'. Blogged reviews offer fuller critical perspectives, but they also provide pithy assessments of the play. John Morrison writes, 'The Knight of the Burning Pestle doesn't have any of the depth of feeling of Shakespeare's great comedies, but it's an exhilarating piss-take with lots of comic potential'; Mark Neal describes the play as 'pre post modern absurdist fun. ${ }^{17}$ Negative responses are interesting too (though apparently, less common). One blogger, Webcowgirl, wrote:

I'm sure this theater is going to be a real asset to London, but whoever picked this show needs a slap in the face with a fish, preferably one that had spoiled a bit, while being heckled by irritated audience members. I've got my salmon, baby, why don't you stand a little closer? ${ }^{18}$

Here, Webcowgirl figures criticism of Pestle in terms which recall something of the anarchic energy of the play itself. Social media responses (good, bad, and indifferent) confirm that Beaumont has an afterlife outside of the theatre, as well as in it. Peter Kirwan notes that Thomas's production succeeded 'apparently effortlessly in generating the most energetic audience [he'd] seen in a theatre in years'. ${ }^{1}$ That energy was not limited to the playhouse but spilt out into tweets, blogs, Facebook comments, and who knows what else. The play will have sparked further unrecorded conversations and observations. The creative, detailed, thoughtful responses which have been recorded attest to the appeal of Pestle and hint at the potential success of other Beaumont plays. Given this success, the Globe not surprisingly revived the play later in 2014, making it the first and to date only sw P production to have been granted a revival.

Although not performed as frequently as Pestle, Beaumont and Fletcher's The Maid's Tragedy has received notable professional productions in the twenty-first century. In 2005, Claire Lovett directed the play at the White Bear, a pub theatre in London. Michael Billington opens his review by asking 'Why isn't Beaumont and Fletcher's tragedy better known?', before praising the relevance of its subject matter ('sex and power'), presentation of 'strong situations', and fluidly accessible language. ${ }^{20}$ To prove that The Maid's Tragedy is relatively unknown Billington adds that 'Lovett's black-box revival is the first since Barry Kyle's 1980 RSC production'. His curious phrasing elides the Globe's 1997 production, directed by Lucy Bailey. By reviewing and praising a fringe theatre production, Billington has helped to raise the profile of Beaumont and Fletcher's tragedy but regrettably he seemingly occludes an important part of the play's performance history. ${ }^{21}$ 
Ultimately, the White Bear production does not seem to have inspired further productions in the UK but the play received professional performances in Canada and the USA. In 2013 Dan Bray directed The Maid's Tragedy for Vile Passéist (now The Villains Theatre), a company based in Halifax, Nova Scotia. One local review opens with a paradoxical assessment of the play. According to Kate Watson, it is 'both an interesting exploration of the social role of women in $17^{\text {th }}$ century European society and a real potboiler of a Jacobean soap opera'. Watson hints at the play's depth and complexity but the dual terms 'potboiler' and 'soap opera', often used to disparage non-Shakespearean Renaissance drama, perhaps imply a lack of subtlety. The review also praises the 'surprisingly accessible language' and the 'good helping of humour, violence and sex'. ${ }^{22}$ The 2014 'Actor's Renaissance Season' American Shakespeare Centre production of The Maid's Tragedy received mixed reviews. Kevin Donovan notes that the production generated unwelcome laughter, a fault which he attributes to changes in theatrical taste: 'the courtly values and melodramatic sensibility that were Fletcher's stock-in-trade, are, it seems, as grotesquely incongruous to a twenty-first century American audience as speeches from Romeo and Juliet were to the denizens of Huxley's Brave New World'. ${ }^{23}$ Some audience members evidently saw the mix of tragedy and comedy as deliberate and successful, however: Eric Minton, for example, noted that the play 'contains a lot of comedy' which was well-handled by the actors. Minton particularly praised the interweaving of humour and suspense in the scene where Evadne ties the King to the bed; the King's lustful confusion meant that the audience were 'juggling laughter with quick-breathed tension'. ${ }^{24}$

A King and No King and Philaster are not performed as regularly as Pestle or The Maid's Tragedy. The American Shakespeare Company has performed both plays this century, however, staging A King and No King at Blackfriars in 2005 and Philaster in 2012. On the one hand, the production of these plays suggests an appetite for Beaumont (and Fletcher) - the company also performed Pestle in 1999, 2003, and 2010 — but their performance does not necessarily constitute an affirmation of their theatrical viability. In a review of the 2005 'Actor's Renaissance Season', Jeremy Lopez suggests that the performers lacked confidence in $A$ King and No King and struggled to deal with Beaumont and Fletcher's dramaturgy: 'on the whole, it did not seem like the actors knew what to make of this play, and as consequence the audience did not either'. ${ }^{25}$ Lopez writes that the performers seemed more comfortable with the interpolated interludes — songs, acrobatics, and dance - than with Beaumont and Fletcher's text; he worries that audiences will 'go away thinking that the plays are kind of a mess anyway and that the actors have done all they could to make an otherwise dull experience 
relatively entertaining. ${ }^{26}$ Unfortunately, audience responses are hard to find; the production does not seem to have left a digital footprint in the manner of the Globe Pestle. Lopez's review of A King and No King is therefore an especially valuable testimony, which calls attention to the dangers, as well as the pleasures, of performing Beaumont and Fletcher.

Responses to the 2012 Philaster are seemingly in short supply too, but another Minton blog post offers useful evidence of an audience response. Minton compares the play favourably with Cymbeline, which was performed alongside Philaster in the Staunton Blackfriars repertory. Minton finds that Beaumont and Fletcher's play is 'much more entertaining', combining 'heartbreaking moments' with 'nonstop intrigue'. The review also mixes some criticism with its praise:

Even if Beaumont and Fletcher created a title character who was a little too onedimensionally heroic, Phelps brought true passion and a visible sense of betrayal to his lines that made the audience want to get up there and convince him he's been misled and his love has been belied. Even if Beaumont and Fletcher made Bellario just a bit too pitiful and wrote two scenes too many with the only purpose of plucking the audience's heartstrings, Donald played the part so truly that our heartstrings nonetheless were plucked in even the two excess scenes. ${ }^{27}$

For Minton, the production succeeded, despite Beaumont and Fletcher's errors. But what Minton sees as an imperfection, Lopez sees as dramaturgical daring: he describes many of Beaumont and Fletcher's scenes as deliberately 'hyperbolical and ridiculous.' ${ }^{28}$ The relative lack of reviews and responses to these productions militates against firmer conclusions about the reception of these plays, but the glimpses we have suggest that Beaumont and Fletcher plays offer peculiar challenges to performers.

So far, I have offered a brief survey of twenty-first century productions of Beaumont plays. I am certain that I have not captured everything but I have tried to attest to some of the more visible productions, paying attention to a range of different critical voices, rather than privileging only commercial and academic viewpoints. My aim has been to sketch out part of the reception history of Beaumont plays. Reviewers and producers of Beaumont (and other non-Shakespearean dramatists) sometimes elide the performance history of his plays. Beaumont is more often performed than we usually assume - that I will have elided some productions myself only strengthens this point. Kiernan Ryan contrasts the culturally central figure of Shakespeare with other dramatists from the time; while Ryan is clear about Shakespeare's relevance, his contemporaries are no more than 
a niche concern 'seldom or never performed and of interest only to academics'. ${ }^{29}$ But even the relatively small amount of data I have collated here shows that Beaumont (and Fletcher) can stimulate a wider audience than merely academics, when they are given the opportunity to do so. The responses I have quoted call attention to the complex challenges placed upon performers of Beaumont and Fletcher plays, but they also suggest that the act of meeting those challenges produces good theatre. The responses are mixed, but respondents tend to stress the striking modern resonances of the plays, rather than treating them like crusty, obscure relics. The success of several of these productions, perhaps especially the 2014 Pestle, might have served as a good starting point for a fuller exploration of the Beaumont and Fletcher canon in Beaumont's anniversary year. Sadly, Beaumont shared that year with somebody else.

\section{Beaumont400}

Shakespeare and Beaumont were not the only literary or theatrical figures for whom 2016 was a significant anniversary. 2016 marked the quatercentenary of the death of Philip Henslowe, Richard Hakluyt, Miguel de Cervantes, and Tang Xianzu, and it was the four hundredth anniversary of the publication of Ben Jonson's folio. On the one hand, Beaumont's stock rose in this company; people who may not have known of Beaumont may have become aware of him because his name was associated with Shakespeare in some of the anniversary celebrations. ${ }^{30}$ On the other hand, Beaumont had to compete for attention, not only with the most celebrated of English authors, but also with other significant writers and literary events. For example, although the RSC paid homage to the anniversary of the Jonson folio it did not acknowledge Beaumont. Trevor Nunn directed Volpone at the RSC's Swan Theatre in 2015 and in 2016 Polly Findlay directed The Alchemist at the same theatre but the company did not produce any Beaumont plays and he did not seem to figure at all in their plans. The RSC's artistic director, Gregory Doran, apparently commissioned Volpone with one eye on 2016:

It's over 12 years since we did Volpone — in that time we've probably done five Romeo and Juliets. Actually, the significant event of 1616 was when Jonson produced the first folio of his work; it was the first time a playwright published their complete works. Had he not done so I doubt we'd have had Shakespeare's First Folio. ${ }^{31}$

For Doran, Jonson's agency comes from Shakespeare, as much as Shakespeare's comes from Jonson; Jonson's folio enabled Shakespeare's, but Shakespeare's 
cultural cachet justifies a return to Jonson's plays. Jonson's apparent influence on Shakespeare permitted his plays to be performed at the RSC in 2016. It is possible to make a similar case for Beaumont: plays like Philaster and $A$ King and No King seem to have helped shape Shakespeare's late career dramaturgy, but the RSC did not attempt to harness these potential connections. ${ }^{32}$ Jonson occupied a secondary position in the RSC's 2016 celebrations but there was no space for Beaumont. ${ }^{33}$

Shakespeare's Globe took a different approach, celebrating a wider range of authors and events. Globe Education's 'Read Not Dead' series included staged readings of Beaumont and Fletcher's The Scornful Lady at Gray's Inn and The Coxcomb at the SWP. Jonson featured as part of this series too; actors performed staged readings of Every Man Out of his Humour and Sejanus, His Fall. These productions offered audiences a valuable chance to see plays which have received very few performances. Notably, despite the success of Pestle in 2014, no full professional productions of Beaumont played at the SWP in 2016. The 2015/16 season included only Shakespeare's late plays, partly, perhaps, to commemorate Shakespeare's anniversary but also, more explicitly, as part of the outgoing artistic director Dominic Dromgoole's farewell. The 2016/17 season, which was performed under the aegis of a new artistic director, Emma Rice, featured relatively few early modern plays: Othello, The White Devil, and Comus were performed alongside modern plays The Little Match Girl and Other Happier Tales and All the Angels. Although Beaumont was clearly a part of the thinking of the Globe's education department in 2016, his plays were not part of the full professional season. A full production of one of Beaumont's less well-known plays like The Scornful Lady or The Coxcomb may have represented too great a risk. But Philaster or A King and No King, in repertory with Shakespeare's late plays (as would have been the case around 1607-12), might have been a viable option. Alternatively, the treatment of jealousy in Philaster may have worked interestingly alongside Othello in the following season. If the idea occurred to either Dromgoole or Rice it was evidently rejected.

Ultimately, it was left to smaller theatre companies to stage full productions of Beaumont in 2016. Edward's Boys, under the direction of Perry Mills, performed The Woman Hater at the RSC's The Other Place in Stratford-upon-Avon, the University of Oxford, the Chapel of King's College, London, Chappelle Maison des Choeurs, Montpellier, and Théâtre sortieOuest, Béziers. The play, which was advertised as solo-authored, was performed partly to raise Beaumont's profile in his anniversary year. An advertising blurb on the company website justifies the play choice more fully: 
If Beaumont is mentioned at all these days it is usually in conjunction with his more famous collaborator John Fletcher (“Bo'mon'n'Fletcha”!) — probably a result of the fact that "Fletcha" also collaborated with someone called Shakespeare. However, Beaumont wrote plays on his own and one at least, The Knight of the Burning Pestle, has a strong reputation following several successful productions in recent decades. ${ }^{34}$

In a rhetorical sleight of hand, the advert figures The Woman Hater as a soloauthored play. Attribution scholars, though, have suggested that Fletcher had a hand in it too; the ascription of the play to Beaumont alone is a comment on the politics of the early modern canon. ${ }^{35}$ Severing Beaumont from Fletcher is a way of severing Beaumont from Shakespeare although, curiously, it is also a way of making Beaumont more like Shakespeare because it mimics the kind of manœuvre routinely used by Shakespeareans. Attribution scholars generally agree that George Peele had a hand in Titus Andronicus and that Thomas Middleton adapted Macbeth but literary critics and theatre producers usually attribute these plays to Shakespeare alone, eliding the contributions of the collaborators. Shakespeare is still, in the main, thought of as a solo-author whereas Beaumont, both now and in his own lifetime, is recognized as a collaborator. Beaumont, then, is refigured as a kind of Shakespearean solo-author; in this disambiguated state he can exert a claim to fame without being seen to rely upon his more prolific (because longer-living) co-author. Perhaps significantly, Pestle, Beaumont's most canonically central work, is his only play routinely described as solo-authored. ${ }^{36}$

But if the advert participates in a Shakespeareanizing of Beaumont the production marked itself as distinctly un-Shakespearean. Reviewers of the production commented on the challenges posed by the play's generic and narrative daring. In an academic review, Harry McCarthy suggests that it was easy to see why The Woman Hater has not been performed for over four hundred years: it takes a company with the energy, versatility, and acumen that Edward's Boys possess in abundance to pull it off'. ${ }^{37}$ In another academic review, Janice Valls-Russell and Florence March attest to the 'various dramatic modes to which the production and cast paid tribute'. ${ }^{38}$ Audiences outside of academia made similar observations: in a Stratford-upon-Avon newspaper review Gill Sutherland praises the play as 'enjoyably ridiculous' even though (or perhaps because) it is also 'a bit of a muddle', while bloggers remark on the play's 'subplots of increasing preposterousness' and its 'forceful, endlessly (sic) parody'. ${ }^{39}$ Reviewers praise the dazzling virtuosity of the boy performers but they commend the play's qualities as well. The Woman Hater seems a very taxing play to perform, perhaps limiting its appeal 
to theatrical producers, but in the hands of Edward's Boys it certainly seems like a play worth performing.

In the USA, Beaumont and Fletcher's The Maid's Tragedy received a full-scale professional production in 2016 courtesy of the Washington DC company Brave Spirits. Whether the play was specifically commissioned for the 2015/2016 season to coincide with Beaumont's anniversary year is unclear; the promotional material does not appear to reference the quatercentenary. Reviews offer conflicting impressions of the play's sophistication. Celia Wren reads The Maid's Tragedy as 'a potboiler about sin, loyalty and revenge' whereas David Siegel argues that it is 'no mere morality play about issues from a time gone-by; built upon onedimensional arch-types representing darkness and light'. ${ }^{40}$ But both reviews are broadly positive in their reception of the play and their appreciation of the performers. Their remarks echo those by reviewers of previous productions. Perhaps still greater exposure to this play might make it possible to challenge the apparently ingrained idea that it is a 'potboiler'. The improved critical reception of Pestle suggests that entrenched assumptions can be overturned by successful, high profile productions. In the last few years North American producers have taken to The Maid's Tragedy much more readily than their UK counterparts. The time is ripe for another UK production of the play and although Beaumont's anniversary passed by without such a performance there are some positive signs that Beaumont's theatrical stock may be beginning to rise. Brave Spirits followed their 2016 Maid's Tragedy with a 2017 production of $A$ King and No King while Bad Quarto Productions, a New York company, performed Beaumont and Fletcher's Cupid's Revenge in the same year. Perhaps these productions, coupled with the success of the Edward's Boys Woman Hater, may yet inspire further theatrical explorations. The RSC and The Globe may have elected to focus their attention elsewhere in 2016 but the Beaumont productions that did take place that year should not be underestimated or elided.

What does the recent performance and reception history of Beaumont tell us about his potential future? In the next section, I reflect upon some possible directions for research, ahead of 2025, when Fletcher, Beaumont's principal collaborator, will receive his own four hundredth year commemoration. Continuing the discussion of recent Beaumont productions, I also offer some ideas about the further study of Beaumont in performance. 


\section{Beaumont and Beyond}

This essay attends to a small part of the stage history of Beaumont's plays but it necessarily leaves much more unsaid. Although Beaumont is not performed as often as some other early modern dramatists, his plays have had a richer theatrical afterlife than is usually acknowledged. By unearthing more details about Beaumont's performance history scholars can learn more about the plays and the challenges they have posed to actors and audiences. Fleshing out the details of these histories may help confirm the plays as theatrically viable and in turn persuade more performers to produce them.

Scholars have emphasized the popularity of Philaster, The Maid's Tragedy, and A King and No King in early modern England but they have perhaps underestimated the theatrical success of Beaumont's other plays. For example, The Woman Hater was performed by the Children of St Pauls by 1607 but Martin Wiggins suggests it may have received further performances by amateur actors in the household of Sir Edward Dering in 1624. He also hypothesizes that it was in the repertory of the Children of the King's Revels at Salisbury Court (under the title The Hungry Courtier) in 1630, and in the same decade (under its original title) in the repertory of the King's Men. ${ }^{41}$ Cupid's Revenge was similarly a hit, not only for the Children of the Queen's Revels (for whom it was written) but later for Lady Elizabeth's Men, who performed it at Whitehall in 1624, and Beeston's Boys, who performed it at St James's Palace in $1637 .{ }^{42}$ The Coxcomb was another Beaumont and Fletcher play performed by several companies, at numerous venues, throughout the early modern period; it was written for the Children of the Queen's Revels but it received further performances by Lady Elizabeth's Men and the King's Men. ${ }^{43}$ The Scornful Lady had a long stage history too: it was performed by the Children of the Queen's Revels and the King's Men and it was scheduled to be performed at the Hague before the Elector Palatine and the Queen of Bohemia in 1629. It was also performed by the King's Men at the Cockpit-in-Court in 1630 and 1642 (it was one of the last plays performed at court before the civil war), as well as privately at Thornton House, Buckinghamshire, in 1638 or 1639 and illegally, at either the Fortune or Salisbury Court, during the theatre ban of the civil war years. ${ }^{44}$ Even Pestle, which scholars tend to read as a failure based on the prefatory material in the first quarto of 1613 , had some success. ${ }^{45}$ Although relatively few remark upon it, Pestle was revived by Queen Henrietta Maria’s Men in the 1630s at the Cockpit/Phoenix playhouse and at St James's Palace in 1636; in 1639, it was in the repertory of the King and Queen's Young Company (also known as Beeston's Boys). ${ }^{46}$ The early modern revivals of Beaumont's plays offer 
an important reminder of the influence Beaumont had on the theatre of the period. Although he did not write many plays, certainly in comparison to Fletcher, he made a significant impact and his plays were valuable commodities. The early history of Beaumont's plays and the roles they may have served in different repertories are topics deserving fuller attention.

Although Beaumont was evidently a popular and successful author in the seventeenth century, his reputation apparently suffered in the late eighteenth and early nineteenth centuries, when Samuel Taylor Coleridge tarred Beaumont and Fletcher as 'servile jure divino royalists'. As Philip Finkelpearl and Sandra Clark have shown, these pronouncements went on to have a considerable effect on later criticism. ${ }^{47}$ Beaumont's knotty reception history, however, warrants further analysis. Ivan Lupić and Brett Greatley-Hirsch have shown the benefits of close attention to Edmond Malone's 1778 edition of Beaumont and Fletcher, demonstrating that Malone's insights into Beaumont and Fletcher's plays outstrip those of many later editors. ${ }^{48}$ There is also room for much more work on Charles Lamb's reception of early modern drama. In Specimens of English Dramatic Poets (1808), Lamb anthologized The Maid's Tragedy, Philaster, and Cupid's Revenge but not The Knight of the Burning Pestle (instead, he listed Triumph of Love as a Beaumont play). Collections by Malone and Lamb, together with adaptations such as The Bridal (1831), which William Charles Macready and James Sheridan Knowles based on The Maid's Tragedy, demonstrate that Beaumont and Fletcher's plays generated a level of interest around this time which scholars too infrequently acknowledge.

The kind of work I have so far described involves historical, archival research, but scholars should also think more about the ways in which they can create archives for future generations. Theatre reviews are one way in which scholars can record the performance of neglected early modern plays. Productions by high-profile companies like the RSC, the Globe, and even Edward's Boys (which has an excellent reputation among scholars of early modern drama) tend to be reviewed but smaller, fringe performances are not always recorded. Reviewers, bloggers, and tweeters do valuable work by writing about such productions, but more is needed. Often, provincial, or small-scale productions will pass by without much comment; it would be a shame to lose the insights they may offer. Additionally, scholars may seek to forge greater connections with performers. While it is easy to find interviews with theatrical practitioners talking about their experiences of playing Shakespeare it is much harder to find interviews with practitioners of non-Shakespearean early modern drama. The fact that Beaumont's plays are much less regularly performed than Shakespeare's makes the testimony of 
Beaumont practitioners even more valuable. Peter Kirwan's interviews with directors and performers of the Shakespeare apocrypha serves as one useful model; these interviews yield fascinating insights about the viability of obscure plays and the challenges of performing them for modern audiences. ${ }^{49}$ As the various accounts discussed in this article demonstrate, Beaumont plays provide considerable challenges to their performers. Listening to the practices of the people who have performed these plays can help to understand those challenges better. Practical work, of the sort undertaken by Michael Cordner in the Dutch Courtesan Project, can also illuminate these challenges. By staging workshops and full productions of early modern plays, Cordner has queried conventional attitudes to performing and editing non-Shakespearean drama. ${ }^{50}$ Beaumont's plays call for modes of performance which are different from those generally required by Shakespeare's plays but reading alone may not make its difference immediately evident. Practical exploration may in turn help encourage further full-scale professional productions.

If such productions are to take place it will be necessary to have good, accessible editions. Clare McManus and Lucy Munro have already outlined the need for a new edition of Fletcher, and the point stands for Beaumont too:

the standard edition - Fredson Bowers' monumental Dramatic Works in the Beaumont and Fletcher Canon (1966-1996) — is rigorous and scholarly, but owing to its use of old-spelling, its heavy, multiple-play volumes, and almost entirely textual focus, keeps both actor and director at arms' length..$^{51}$

Certainly, the less well-known Beaumont plays are not easily available and even some of the better-known ones could be updated. At the time of writing, complete works of John Ford, James Shirley, Thomas Heywood, and John Marston are in progress. While a new Beaumont and Fletcher edition would be an enormous undertaking, it may soon be necessary to start one, to keep Beaumont and Fletcher from lagging behind their contemporaries. New editions come with a variety of benefits, of course, but increased potential for further dramatic productions is one exciting possibility.

\section{Endings and Beginnings}

At the start of this article I posed two questions: how was Beaumont commemorated in 2016? What can be done to give Beaumont the attention he deserves? In the UK, Beaumont received more theatrical attention than he would have 
done ordinarily. From one perspective, this is a welcome improvement. Indeed, I have argued that the productions which did take place in 2016 should be celebrated and studied, not maligned or elided. Even so, curiously, Beaumont did not feature much in the Globe's plans, despite the success of the 2014 Pestle; so too, the RSC chose to commemorate the Jonson folio but did not mention Beaumont. Beaumont plays may have complemented the repertories offered by both theatre companies. But it is difficult to be too critical of the programming of these theatre seasons given that Beaumont received comparatively little academic attention either. If scholars want to see more Beaumont in the theatre, they may need to generate more work to raise his profile. This essay has suggested several possible directions for future work. I want to end, though, by considering an undeclared assumption underpinning this article: that Beaumont is worth special attention.

Throughout this essay I have tended to treat Beaumont as a solo author, even though I have acknowledged that doing so is problematic. On the one hand, as Jeffrey Masten argues, a single-author model effaces Fletcher and strips away some of the complexity of the craft which went into writing some of the most significant plays of the seventeenth century. ${ }^{52}$ On the other hand, disambiguating Beaumont from Fletcher can help us to see the achievement of Beaumont more clearly. John Jowett and David Nicol have both argued that the process of disintegrating texts can make different kinds of playwrighting practices more visible. ${ }^{53}$ Gordon McMullan's work on John Fletcher may be a useful case in point. McMullan notes:

The main Beaumont and Fletcher collaborations - The Woman Hater (chiefly Beaumont's), Cupid's Revenge (dominated by, and final version by, Beaumont), Philaster (chiefly Beaumont's), The Maid's Tragedy (chiefly Beaumont's), and A King and No King (also chiefly Beaumont's) - provide clear evidence of Fletcher's regular subordination to his younger partner in the writing process. ${ }^{54}$

More attribution tests are needed, but if this calculation is right, it is striking. Fletcher, the more prolific dramatist (and a known collaborator with Shakespeare), receives more critical attention than Beaumont, but Beaumont seems to have taken the lead on several of the most celebrated plays in either author's canon. It is crude to suggest that the author who contributed most in a collaboration is best and I see no value in trying to argue that Beaumont is better than Fletcher (or vice versa), but perhaps we should acknowledge that Beaumont more than pulled his weight in the collaboration. As Fletcher's quatercentenary celebration is likely 
to be bigger than Beaumont's, it will be important to ensure that Beaumont is not squeezed out of the picture in 2025.

Indeed, scholars should be wary of making any single author into a surrogate Shakespeare-figure. This is one danger with marking Beaumont out as a writer worthy of special attention. One way around this problem is to view Beaumont in relation to his contemporaries, and here I mean not only Fletcher, but other authors with whom his work is in dialogue. But above all, I think, especially when it comes to the performance of early modern plays, anything is better than nothing. On the morning of the Beaumont 400 conference from which this 'Issues in Review' segment originated, the Shakespeare 400 Twitter account cheerily announced 'Beaumont 400 ends today' (@S400events; 12 March 2016). A premature ending is perhaps the greatest problem for Beaumont (and for any early modern author who is not Shakespeare). Perhaps the other problem Beaumont might face is the perpetual beginning. As we have seen, productions of his plays are often elided; each time this happens it as if the clock is reset and Beaumont must begin again. Like other non-Shakespearean dramatists, Beaumont is always beginning, but rarely begun. Too many of these beginnings stay as beginnings, rather than becoming middles. Or worse still, they become ends. 


\section{Notes}

1 Ian Donaldson, Ben Jonson: A Life (Oxford, 2011), 428. See also Donaldson, 'Why was Shakespeare's death such a non-event at the time?', The Conversation, 14 November 2016, https://theconversation.com/why-was-shakespeares-death-such-a-nonevent-at-the-time-68713.

2 Peter Holland, 'Shakespeare and Biography', in Shakespeare in Our Time: A Shakespeare Association of America Collection, ed. Dympna Callaghan and Suzanne Gossett (London, 2016), 252.

3 'Beaumont, Francis (1584/5-1616)', Oxford Dictionary of National Biography. Recently, Lucy Munro, Gordon McMullan, Lucia Bay, and Irene Jacobs have shed light on a newly restored portrait of Beaumont, but this kind of attention to Beaumont's biography is rare; see their 'Procuring Audience', Times Literary Supplement, 18 January 2017. For further biographical exploration, see also Munro's 'Beaumont's Lives' essay in this 'Issues in Review' forum.

4 David Bevington, Shakespeare and Biography (Oxford, 2010), 1.

5 'Why Read Shakespeare's Complete Works?', Gary Taylor, John Jowett, Terri Bourus, and Gabriel Egan (eds), The New Oxford Shakespeare: Modern Critical Edition (Oxford, 2016), 1, https://doi.org/10.1093/actrade/9780199591152.book.1.

6 Karin Brown, 'Professional productions of early modern drama in the UK and USA, 1960-2010', Performing Early Modern Drama Today, ed. Pascale Aebischer and Kathryn Prince (Cambridge, 2012), 178-217.

7 Jeremy Lopez, 'Performances of early modern drama at academic institutions since 1909', in Aebisher and Prince (eds), Performing Early Modern Drama Today, 218-24; Jeremy Lopez, 'Performances of early modern plays by amateur and student groups since 1887', in the same volume, 225-27.

8 Jeremy Lopez, 'The seeds of time: student theatre and the drama of Shakespeare's contemporaries', in Aebisher and Prince (eds), Performing Early Modern Drama Today, 50.

9 Lyn Gardner, 'The Knight of the Burning Pestle', Guardian, 1 October 2005.

10 Charles Spencer, 'The unfunniest show in town', Telegraph, 4 October 2005.

11 Fiona Mountford, 'Knight of much confusion', Evening Standard, 30 September 2005.

12 Sarah Hemming, 'Knight of the Burning Pestle review', Financial Times, 4 October 2005. 
13 Lucy Munro, 'The early modern repertory and the performance of Shakespeare's contemporaries today', Aebisher and Prince (eds), Performing Early Modern Drama Today 21.

14 Dominic Cavendish, 'The Knight of the Burning Pestle, Sam Wanamaker Playhouse, review', Telegraph, 27 February 2014; Michael Billington, 'The Knight of the Burning Pestle review — "A spirited romp by candlelight", Guardian, 27 February 2014.

15 Fiona Mountford, 'The Knight of the Burning Pestle, Sam Wanamaker Playhouse - theatre review', Evening Standard, 27 February 2014.

16 Paul Taylor, 'The Knight of the Burning Pestle, theatre review', Independent, 27 February 2014.

17 John Morrison, 'The Knight of the Burning Pestle', Black Pig, http://blackpig. typepad.com/john morrison/2014/02/the-knight-of-the-burning-pestle.html; Mark Neal, 'Review: The Knight of the Burning Pestle by Francis Beaumont, at the Sam Wanamaker Playhouse', Migrant Press, http://migrantpress.blogspot. co.uk/2014/02/review-knight-of-burning-pestle-by.html. Julie Raby usefully storifies responses to the play, making searching the online archive easier: https://storify. com/Julie raby/the-knight-of-the-burning-pestle-sam-wanamaker-pla.

18 'Review — The Knight of the Burning Pestle — Sam Wanamaker Playhouse at Shakespeare's Globe', Webcowgirl, https://webcowgirl.wordpress.com/2014/03/13/reviewthe-knight-of-the-burning-pestle-sam-wanamaker-playhouse-at-shakespearesglobel.

19 Peter Kirwan, 'The Knight of the Burning Pestle (Shakespeare’s Globe) @ The Sam Wanamaker Playhouse', The Bardathon, http://blogs.nottingham.ac.uk/ bardathon/2014/03/23/the-knight-of-the-burning-pestle-shakespeares-globe -the-sam-wanamaker-playhouse/.

20 Michael Billington, 'The Maid's Tragedy', Guardian, 28 June 2005.

21 For commercial reviews of this production, see Theatre Record 17 (1997), 1084-7.

22 Kate Watson, 'The Maid's Tragedy', The Coast, 17 November 2013, https://www. thecoast.ca/halifax/the-maids-tragedy/Content?oid=4125466.

23 Kevin Donovan, 'The Maid's Tragedy, Epicene and As You Like It, presented by the American Shakespeare Center', Early Modern Literary Studies 17 (2014), 3, https:// extra.shu.ac.uk/emls/journal/index.php/emls/article/view/205. Bailey's 1997 Globe production received similar criticisms; W.B. Worthen discusses this in the context of the Globe's house style in his Shakespeare and the Force of Modern Performance (Cambridge, 2003), 100-1. 
24 Eric Minton, 'A Maid's Unmaking of a Man, A Moment Made for Live Theater', Shakespeareances.com, http://www.shakespeareances.com/willpower/nonshakespeare IMaids Tragedy-01-ASC14.html.

25 Jeremy Lopez, 'The Tamer Tamed and A King and No King', Shakespeare Bulletin 23 (2005), 112. Donovan makes some similar criticisms of the 2014 American Shakespeare Centre Maid's Tragedy in 'The Maid's Tragedy, Epicene and As You Like It', 4.

26 Lopez, 'The Tamer Tamed and A King and No King', 114.

27 Eric Minton, 'Out of Archetypes Rises a Splendid Play', Shakespeareances.com, http:// shakespeareances.com/willpower/nonshakespeare/Philaster-01-ASC12.html.

28 Lopez. 'The Tamer Tamed and A King and No King', 112. See also Lee Bliss (ed.), A King and No King (Manchester, 2004), 30-1, and Suzanne Gossett (ed.), Philaster (London, 2009) 52-8. For a negative assessment, see Eugene Waith, Pattern of Tragicomedy (New Haven, 1952), 154.

29 Kiernan Ryan, Shakespeare's Universality: Here's Fine Revolution (London, 2015), 4.

30 For example, Shakespeare's Globe acknowledged the many anniversaries celebrated in 2016; see '1616: A Momentous Year', http://www.shakespearesglobe.com/1616.

31 Dominic Cavendish, 'Gregory Doran interview: Getting the RSC just as he likes it', Telegraph 23 January 2013, http://www.telegraph.co.uk/culture/theatre/theatre-features/9818817/Gregory-Doran-interview-Getting-the-RSC-just-as-he-likes-it.html.

32 Indeed, Lucy Munro has offered the fascinating suggestion that Beaumont, Fletcher, and Shakespeare may even have collaborated on the lost Cardenio: 'His collaborator John Fletcher', in The Shakespeare Circle: An Alternative Biography, ed. Paul Edmondson and Stanley Wells (Cambridge, 2015), 310. https://doi.org/10.1111/ heyj. 12540 .

33 The RSC also produced a version of Cervantes's Don Quixote, adapted by James Fenton and directed by Angus Jackson.

34 Edward's Boys, http://www.edwardsboys.org/edwards-boys-present-the-woman -hater-by-francis-beaumont/.

35 Cyrus Hoy, 'The Shares of Fletcher and His Collaborators in the Beaumont and Fletcher Canon (III)', Studies in Bibliography 11 (1958), 98. In the production's programme, Stanley Wells and Lucy Munro refer to the play as co-authored, while Gordon McMullan attributes it to Beaumont alone: http://www.edwardsboys.org/ wp-content/uploads/2016/05/TWH-programme-final-condensed.pdf.

36 Jeffrey Masten takes a different view, noting that, although putatively solo-authored, Pestle is 'perhaps the most wildly collaborative play of the period': Textual Intercourse: Collaboration, Authorship, and Sexualities in Renaissance Drama (Cambridge, 1997), 23. 
37 Harry R. McCarthy, 'The Woman Hater Presented by Edward's Boys', Shakespeare Bulletin 34 (2016), 723, http://doi.org/10.1353/shb.2016.0063.

38 Janice Valls-Russell and Florence March, 'The Woman Hater by Francis Beaumont, directed by Perry Mills for Edward's Boys', Cahiers Élisabéthains 91 (2016), 132.

39 Gill Sutherland, 'Pushing the boundaries right from day one', Stratford-upon-Avon Herald, 22 March 2016; 'And the piece of Cod, which passeth all understanding', The Bard of Tysoe https://tysoebard.blogspot.co.uk/2016/03/and-piece-of-cod-which-passeth-all.html; Roderic Dunnett, 'The Woman Hater', Behind the Arras, http://www.behindthearras.com/reviewsam/reviewAMJanmar2016/the-woman -hater-KES03-16.html.

40 Celia Wren, 'Theatre reviews: “The Maid's Tragedy" and "Antigone Project: A Play in Five Parts"', Washington Post, 23 February 2016; David Siegel, 'Review: "The Maid's Tragedy" at Brave Spirits Theatre', DC Metro Theater Arts, 21 February 2016, http://dcmetrotheaterarts.com/2016/02/21/189635/.

41 Martin Wiggins in association with Catherine Richardson, British Drama 15331642: A Catalogue, 7 vols (Oxford, 2012-16), 5.342.

42 Ibid, 5.380.

43 Ibid, 6.24.

44 Ibid, 6.101.

45 Jeremy Lopez argues that the play's failure may be overstated: Constructing the Canon of Early Modern Drama (Cambridge, 2014), 75.

46 Wiggins with Richardson, British Drama 1533-1642, 5. 436.

47 Philip J. Finkelpearl, Court and Country Politics in the Plays of Beaumont and Fletcher (Princeton, 1990), 5, https://doi.org/10.1515/9781400860722; Sandra Clark, The Plays of Beaumont and Fletcher: Sexual Themes and Dramatic Representation (London, 1994), 3-4.

48 Ivan Lupić and Brett Greatley-Hirsch, "What stuff is here?” Edmond Malone and the 1778 Edition of Beaumont and Fletcher', Papers of the Bibliographical Society of America 111 (2007), 287-315, https://doi.org/10.1086/692741.

49 Peter Kirwan, 'From Script to Stage', in William Shakespeare and Others: Collaborative Plays, ed. Jonathan Bate and Eric Rasmussen (Basingstoke, 2013), 746-82, http://dx.doi.org/10.1007/978-1-137-27145-7.

50 Michael Cordner and Oliver Jones, http://www.dutchcourtesan.co.uk/. See also Oliver Jones, 'The Dutch Courtesan Online', Shakespeare Bulletin 33 (2015), 623-39, http://dx.doi.org/10.1353/shb.2015.0067.

51 Clare McManus and Lucy Munro, 'Introduction: Shakespeare and Fletcher, Fletcher and Shakespeare', Shakespeare 7 (2011), 254, https://doi.org/10.1080/17450918.2011. 589074 . 
52 Masten, Textual Intercourse, 113-55.

53 John Jowett, 'Disintegration, 1924', Shakespeare, 10 (2014), 171-87, http://dx.doi. org/10.1080/17450918.2013.833981; David Nicol, Middleton and Rowley: Forms of Collaboration in the Jacobean Playhouse (Toronto, 2012), 8-9.

54 Gordon McMullan, The Politics of Unease in the Plays of John Fletcher (Amherst, 1994), 143. 
